\title{
Stenting of Carotid Artery Using the Brachial Artery Approach
}

\author{
Brakiyal Arter Yoluyla Karotis Artere Stent Uygulaması
}

(1) Gökhan Özdemir, (1) Gözde Ongun

Selcuk University Faculty of Medicine, Department of Neurology, Konya, Turkey

Keywords: Carotid artery stenosis, brachial artery, carotid artery stenting, transient ischemic attack

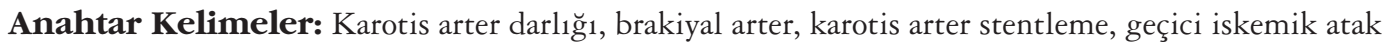

\section{Dear Editor,}

Carotid artery stenosis (CAS) is one of the most important causes of ischemic stroke and is responsible for approximately 25$30 \%$ of all strokes $(1,2)$. In addition to endarterectomy, balloon angioplasty and persistent stenting can be used in the treatment of CAS. Endovascular interventions, being minimally invasive methods, have low mortality and morbidity. In addition, it decreases the length of hospital stay and is used frequently in the treatment of vascular diseases. In endovascular procedures for the carotid artery, the femoral artery is usually used because it has a large diameter and is generally easier to reach. We aimed to share a rare procedure in the literature because we used a trans-brachial approach for carotid artery stenting due to bilaterally occluded femoral arteries.

A 61-year-old male patient with a history of hypertension, diabetes mellitus, cardiac bypass, and transient ischemic attack was admitted to the Chest Diseases Outpatient Clinic for chest pain and shortness of breath. Computed tomography angiography revealed approximately $70 \%$ stenosis in the lumen of the proximal segment of the left common carotid artery (CCA). The patient was referred to us because the right internal carotid artery (ICA) was totally occluded right after a short stump from its origin and there were calcified plaques in the left carotid bulb that did not cause any significant stenosis. The patient was hospitalized for diagnostic angiography. The patient, whose neurologic examination was within normal limits, underwent angiography. Angiography revealed that the femoral arteries were bilaterally occluded. A 6-French introducer sheath was placed into the right radial artery. Diagnostic angiography was performed using a 5-F vertebral catheter. A bovine arc was observed. The right ICA was occluded proximally. A plaque was observed in the proximal left ICA without significant stenosis. In the left CCA, more than 50\% stenosis with regular margins was observed. Bilateral anterior system was filling from the left ICA. Abdominal aortography was performed. The right iliac artery was completely occluded, and stenosis and a surgical graft were observed on the left. A repeat angiography was planned for the next day for stenting. A 7-F introducer sheath was placed into the right brachial artery. The left CCA ostium was accessed with a 7-F guiding catheter (Figure 1). The 6-20 distal filter was opened in the petrosal segment of ICA. A 9-7-30 "self-expandable" stent was opened in the lesion (Figure 2). Post-dilatation was performed with a 6-20 noncompliant balloon for residual stenosis. Extra- and intra-cranial images were obtained. It was observed that the anterior system was fed from the left carotid artery (Figure 3). The procedure was completed without complications. No bleeding or thrombosis occurred after the withdrawal of the sheath. The patient was mobilized after 30 minutes. The following day, the patient was referred to Cardiovascular Surgery Clinic because of bilateral femoral occlusion.

Stroke is the second most common cause of death and is a serious public health problem with serious morbidity. Asymptomatic or symptomatic, a thromboembolic material that develops on the basis of CAS and posterior system stenosis may lead to an occlusive stroke in the cerebrovascular system (3). Approximately $75 \%$ of ischemic strokes originate from the anterior system (3). In one-third of these,

\footnotetext{
Address for Correspondence/Yazışma Adresi: Gökhan Özdemir MD, Selcuk University Faculty of Medicine, Department of Neurology, Konya, Turkey Phone: +90 5301187786 E-mail: noro.ozdemir@gmail.com ORCID ID: orcid.org/0000-0001-8140-6333

Received/Geliss Tarihi: 21.10.2018 Accepted/Kabul Tarihi: 07.01.2019

${ }^{\circ}$ Copyright 2019 by Turkish Neurological Society

Turkish Journal of Neurology published by Galenos Publishing House.
} 


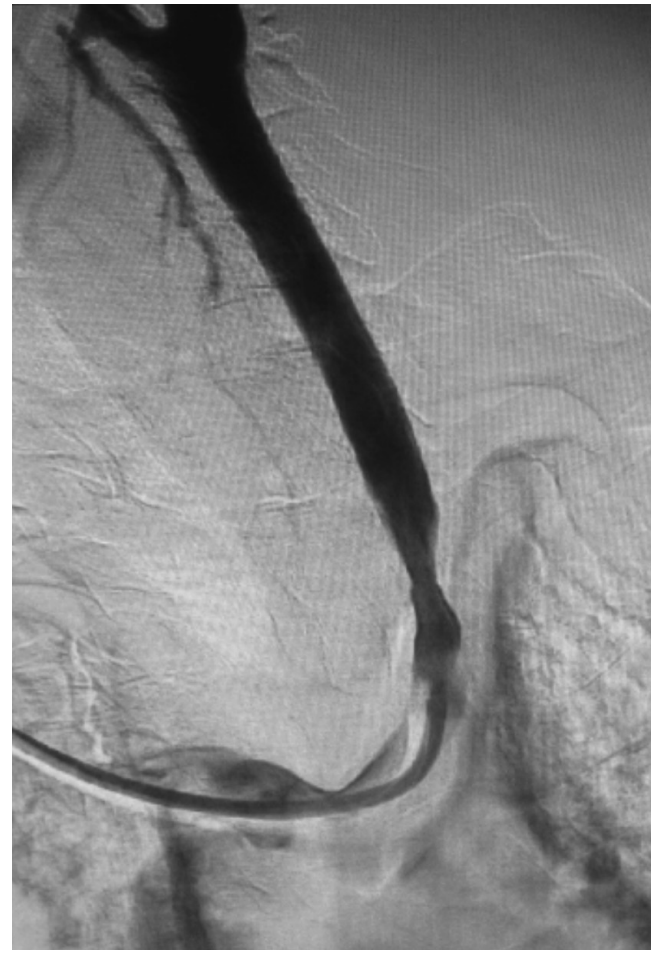

Figure 1. Stenosis is observed in the proximal left common carotid artery following contrast agent administration through 7-F guiding catheter in the right brachial artery

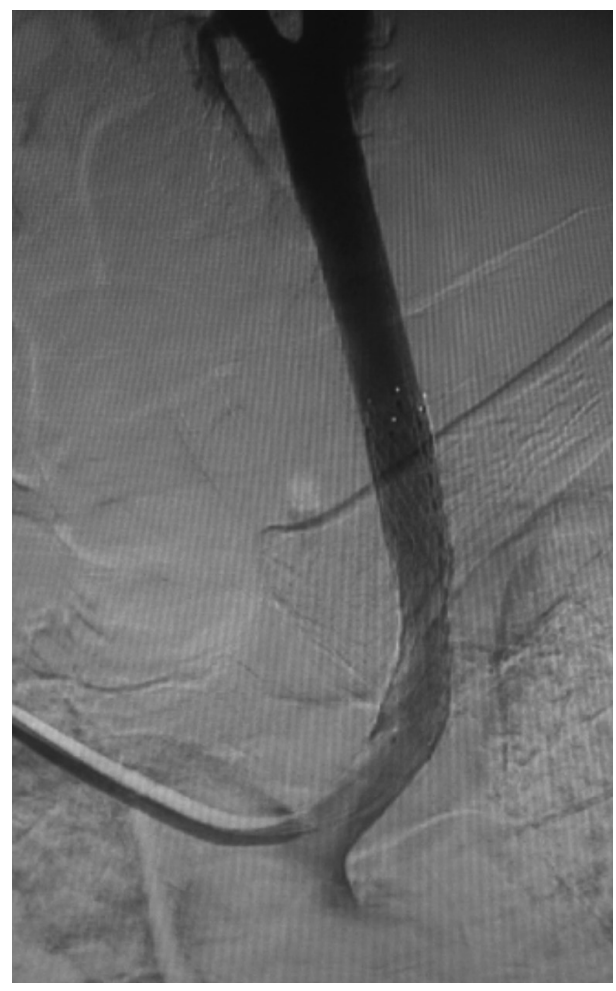

Figure 2. After the procedure, the self-expandable stent placed in the left common carotid artery was intact and the stenosis was opened

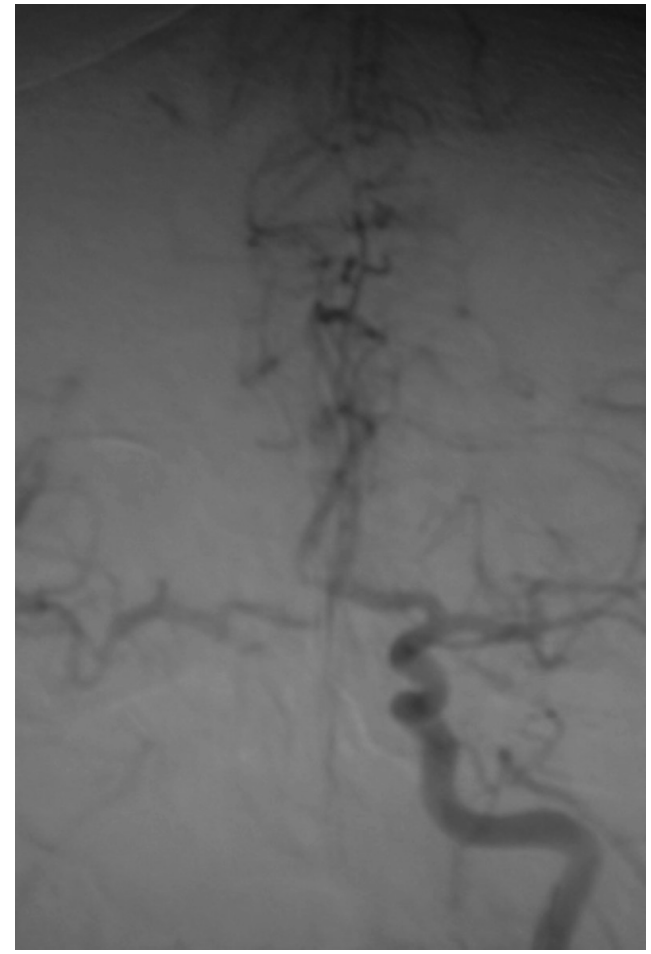

Figure 3. The anterior system of the patient with right internal carotid artery (ICA) occlusion is observed to be completely fed by the left ICA. This shows us that the anterior communicating artery and the Willis polygon are important

the reason is CAS. Therefore, the diagnosis and treatment of CAS are very important. Medical treatment, endarterectomy, balloon angioplasty, and stenting are used in the treatment of CAS. In parallel with technological developments, balloon angioplasty and stenting have emerged as an alternative to carotid endarterectomy. In these applications, the right femoral artery is used primarily, and the left femoral artery is used secondarily. The reason for the frequent use of the femoral artery is that this larger artery is comfortable to use with large diameter guide catheters and other devices (4). Carotid artery stenting using the trans-radial approach has recently been reported with a success rate of $90 \%$. In addition, the incidence of bleeding related to the site of intervention is lower than in trans-brachial and trans-femoral approaches; however, significant spasms may occur during radial artery access. These factors create limitations in the use of the radial artery. Therefore, we preferred to use the brachial artery. Interventions performed through the brachial artery are known to increase patient comfort over the femoral route; however, an important problem in transbrachial interventional procedures is thrombosis at the sheath site or bleeding complications during early withdrawal (5). In our case, complications such as bleeding or thrombosis were not observed and the stent was placed as "intact". In this case, we have proven that the use of the brachial artery is effective and reliable in carotid stenting and can be performed easily in neurology clinics. In addition, we believe that methods that provide patient comfort without increasing the complication rate will be used more widely in the next periods in carotid artery stenting. 
Ethics

Informed Consent: Consent form was filled out by all participants.

Peer-review: Internally peer-reviewed.

\section{Authorship Contributions}

Surgical and Medical Practices: G.Ö., G.O., Concept: G.Ö., G.O., Design: G.Ö., G.O., Data Collection or Processing: G.Ö., G.O., Analysis or Interpretation: G.Ö., G.O., Literature Search: G.Ö., G.O., Writing: G.Ö., G.O.

Conflict of Interest: No conflict of interest was declared by the authors.

Financial Disclosure: The authors declared that this study received no financial support.

\section{References}

1. Polat N, Elbey MA, Akıl E, ve ark. Karotis artere stent yerleştirme: Tek merkez deneyimi ve klinik sonuçları. Dicle Tip Dergisi 2014;41:685-689.

2. Hıdıroğlu M, Çetin L, Kunt A, ve ark. Karotis arter hastalıklarında karotis endarterektomi erken sonuçları. Turk Gogus Kalp Damar Derg 2010;18:190195.

3. Özdemir G, Öngün G, Kızıldağ N, Kocatürk İ. Aynı seansta vertebral ve karotis arter stentleme olgu sunumu. Türk Beyin Damar Has Derg 2018;24:87-89.

4. Goldberg SL, Renslo R, Sinow R, French WJ. Learning curve in the use of the radial artery as vascular access in the performance of percutaneous transluminal coronary angioplasty. Cathet Cardiovasc Diagn 1998;45:215216.

5. Kiemeneij F, Laarman GJ. Transradial artery Palmaz-Schatz coronary stent implantation: results of a single-center feasibility study. Am Heart J 1995;130:14-21. 